УДК 7.022 .26

\title{
Musical Interests and Priorities \\ of Vladimir Lenin \\ (Modern Vision)
}

Emil’ M. Preisman*

Krasnoyarsk State Academy of Music and Theatre 22 Lenin Str., Krasnoyarsk, 660049, Russia

Received 12.10.2014, received in revised form 06.01.2015, accepted 29.01.2015

In modern Russia the problem of cultural education, including musical and aesthetic one, has become quite acute as one of the barriers on the way of globalization negative impacts. After Perestroika, the work on cultural education has been significantly reduced. In the search for modern approaches to its reestablishment, the author suggests to turn to the experience of the past and, in particular, to study the attitude of Vladimir Lenin to music, who though not being an expert in the field, but as a politician believed that cultural education of the people is important and prospective.

Keywords: Lenin, music, musical and aesthetic education, opera, symphonic music, quartet, piano music, vocal lyrics, art songs, songs.

Research area: art history.

It is well known that the world is under the pressure of globalization. This phenomenon is mainly economic, nevertheless affecting all the spheres of human life and activities. ${ }^{1}$ In the cultural field, globalization leads to leveling of national and religious identity of cultures, substitution of cultural values of different nations and countries by aggressively imposed, adjusted for empty-headed consumption, socalled "western values" leading to downplaying of the personality, making it easy to impose, and, therefore, easy to control. Let us note that globalization provides the most dangerous effect on young people, while it is the mind and hands of modern youngsters, which will create the future.
Therefore, opposing globalization is natural. In the cultural field, the priority for Russia is counteraction to the imposing of the alien way of thinking in the field of culture, first of all moral, determining other types of cultures as well, including musical.

The attitude to musical culture is extremely important, while the language of music with its profound emotional impact is a mediator of both the high level of cultural values and intoxicating bright advertising in opposition to the skillfully "packed" grayness.

It is obvious, that to differentiate between grains and weed one should have general musical education, which means not only learning how to play a musical instrument, but also learning how

(C) Siberian Federal University. All rights reserved

* Corresponding author E-mail address: preisman@list.ru 
to listen and understand music, comprehend its vocabulary and semantics. In the national practice of the second half of the $20^{\text {th }}$ century, exposure to this kind of art has got the name of "musical and aesthetic education".

One of the ways to arise interest to any kind of art can be an example of how prominent personalities of the past and the present treat it. Outstanding representatives of the Russian intelligentsia, who had not studied music professionally, demonstrate big interest in music, typical for Russia, understanding the unfading value of its best samples. Thus, Griboedov played the piano and his Waltz is included in the concert and educational repertoire of pianists. Leo Tolstoy, already a world-famous author of "War and Peace", was practicing the piano every day. Mikhail Lermontov learnt to play the piano, violin and flute. N.F. Sklifosofsky and V.K. Khoroshko at various times had been participants of the amateur symphonic orchestra of Moscow University. V.I. Surikov had been playing the guitar from the young age. P. Annenkova recalls that the Decembrists General A.P. Yushnevsky and officers F.F. Vladkovsky, A.A. Kryukov and P.N. Svistunov played music in quartet in the Chita ostrog [Annenkova 1977: 147].

The gift of listening to music is also valuable. Thus, S.T. Konenkov wrote, "I can not imagine a creative life without music. Without it, I lack imagination and inspiration. It moves ... poetry and architecture, it is invisibly present in all deep and intimate feelings of the human" [Konenkov, 1968: 11]. L.A. Kassil also writes about music with love [Kassil, 1968: 1214]. A.S. Pushkin, L.N. Andreev, A.I. Kuprin, A.M. Gorky, K.I. Chukovsky, M.M. Prishvin, B.M. Kustodiev, S.P. Botkin, L.B. Krasin, P.L. Kapitsa, L.M. Roshal ${ }^{2}$, many other stars of Russian literature, art and science had extensive knowledge in the field of music.
In the spiritual life of the Soviet society, a special place was occupied by art, including musical, interests and priorities of Vladimir Lenin. The opinion of the founder of the Soviet state, which was considered the ultimate truth (in all scientific and journalistic publications of all fields of knowledge there were references to his works), was an example of how one should love music and served as a strong ideological basis of musical enlightenment.

Lenin's family and friends also wrote about his attitude to music: D.I. Ulyanov [Ulyanov, 1956: 69-70], Krupskaya [Krupskaya, 1960: 155-160], supporters of the party work M.S. Kedrov [Kedrov, 1986: 459], M.M. Essen [Essen 1969: 115-117]. Lenin's gift of listening to music was described by Gorky [Gorky 1974: 7-49], Krupskaya [Krupskaya, 1960: 115-160], P.N. Lepeshinsky [Lepeshinsky, 1955: 451-452] et al.

There are works of musicologists on the role of music in the life of Lenin: A.A. Alshvang and V.A. Zuckerman [Alshvang, Zuckerman, 1970: 28-44] L.N. Raaben [Raaben, 1969: 172-202], K.K. Rozenshild [Rozenshild, 1970: 5-27].

In the study of musical interests of Lenin the works by L.A. Ureklian (1902-1974), who was the supervisor of the scientific and educational department of the StateCentralMuseumofMusical Culture named after Glinka in 1948-1956, should be noted. There are several articles by Ureklian about Lenin's attitude to music, published in the journal "Theater" and "Musical Life", as well as in the journals of Yerevan and Tallinn. The author of these lines has a typewritten copy of several fragments of Ureklian's book about the role of music in the life of Lenin totaling 79 typewritten pages, double-spaced [Ureklian, 1963].

Ureklian connects Lenin's musical interests with his worldview and activities. The author describes some of the facts of the musical life, witnessed by Lenin, but questioned or concealed 
by memoir writers. Ureklian convincingly reasons these facts by references to literature, such as Volga press of the end of the $19^{\text {th }}$ century: Lenin going to opera performances of P. Medvedev's touring company in 1888 during his life in Kazan when he was under police surveillance already. The author also provides information about Lenin's favourite music pieces. In general, a lot of space in the work of Ureklian is given to the circumstances around the music that was among Lenin's interests.

Lenin himself briefly refers to his musical impressions only in several letters [Krupskaya, Lenin, 1985: 346-347; Lenin, 1982: 75; Lenin, 1983: 202, 229].

However, significant amount of literature on the musical interests of Lenin does not contain information about his likes and dislikes in this field. The music he listened to, has not been classified by periods, styles and genres, there have not been any comments on his attitude to the programme and non-programme music, no attempts to make any generalization of his musical interests in the field of professional music, his vision of the role of music in the course of construction of the socialist society has not been outlined.

The purpose of this work is to demonstrate understanding of the role of music in the life and work of Lenin. Therefore, the author aims at differentiating music, which was interesting for Lenin, by periods and genres, identification, if possible, of the causes of his musical likes and dislikes, understanding of Lenin's vision of music as an instrument of ideology and determination of the extent to which an example of Lenin's attitude - an outstanding representative of the humanity - to the art of music is significant for the modern Russian society.

Lenin was brought up in an intellectual family, which considered music to be an essential component of good education and a means of recreation. In the $19^{\text {th }}-$ early $20^{\text {th }}$ century, when there was no means of recording and remote transmission of sound, the only way to get acquainted with music was live performance. Therefore, in financially secure families children were taught music. In the $19^{\text {th }}$ century, piano adaptations of various music for domestic musicmaking were in great demand. (Would not it be awkward to ride the horses from Simbirsk to Moscow or Saratov only to listen to an opera or a symphony concert?)

Lenin's mother, Maria Aleksandrovna, played the piano and sang well. She taught her children music as well: Vladimir Ilyich and Olga Ilyinichna. D.I. Ulyanov recalls, “... according to his mother, Lenin had a great ear for music and it was easy for him to learn how to play. When he was eight years old, he could easily play many children's music and also played duets with the elders... In 1888-1890, Vladimir Ilyich often sang with his sister Olga Ilyinichna playing the piano" [Ulyanov, 1956: 69].

The Ulyanovs had a music library in their house. It contained piano adaptations of many operas, piano scores of "Life for the Tsar", "Faust", "La Traviata", "Rigoletto". (In 1963, L.A. Ureklian wrote that later this library was transferred to the museum-apartment of Lenin in the Kremlin [Ureklian, 1963: 23]). Maria Aleksandrovna and Olga Ilyinichna often performed piano score of the fragments of the operas of Mozart "The Marriage of Figaro", Bellini - "Puritans", "La Sonnambula", Donizetti - "Elixir of Love", "Daughter of the Regiment", Weber - "Der Freischütz", Meyerbeer - "Les Huguenots", Verdi - "Il Trovatore", Bizet - "Carmen", Wagner - "Lohengrin" and "Tannhauser", Glinka - "Ruslan and Lyudmila", Rubinstein "Demon", Borodin - "Prince Igor" Tchaikovsky "Eugene Onegin" [Ureklian, 1963: 14]. It is noteworthy, that the operas "Demon" created in 1871, “Carmen” (1875), "Eugene Onegin” (1878) and "Prince Igor" (1890) were then contemporary 
music, i.e. Lenin was to a certain extent aware of the development of the European opera.

One of the favourite operas of the younger generation of the Ulyanovs was "Askold's Grave" by Verstovsky. Lenin's cousin N.I. Veretennikov recalled that in Kokushkino, a small village near Kazan, where the Ulyanov family usually rested in the summer, Maria Aleksandrovna was giving a vivid story of the opera, illustrating it by music and singing. Ulyanov children were deeply impressed by it [Ureklian, 1963: 14, 15].

From the memoirs of A.F. Shcherbo, a friend of O.I. Ulyanova, we know that Lenin listened to the opera in Simbirsk. According to some data specified by L.A. Ureklian, in April 1885, Lenin-schoolboy attended the performance of "Aida" and possibly others performed by P.M. Medvedev's company: "La Traviata", "Rigoletto", "Faust", "Halka", "Life for the Tsar", "Mermaid" [Ureklian, 1963: 20].

D.I. Ulyanov recalls that in 1988 he and eighteen-year-old Lenin listened to the opera in Kazan "at the time, Ureklian writes, of the shortterm management of the theater by A.A. OrlovSokolovskii", an outstanding conductor and musical figure [Ureklian, 1963: 24]. We know the kind of music piece Lenin was listening to from his letters to his mother on February 9, 1901 in Munich: I have recently been in the opera, listening to "La Juive"3 with great pleasure: I heard it once in Kazan (when Yu.F. Zakrzewski was signing), about 13 years ago, but some moments remained in the memory. Music and singing were good [Lenin, 1983: 202].

The Ulyanovs with their strong musical memory, often sang something, in between times, including fragments from operas. Dmitry Ilyich Ulyanov wrote that Lenin "also sang Valentine's aria from "Faust”, “Бог всесильный, бог любви ..." - he sang according to the music, saying the words that could not be taken out of the song, but he sang one passage from this aria better, more beautiful because he involuntarily put a part of his fighting spirit in it, “Там в кровавой борьбе в час сраженья, / Клянусь, буду первым я в первых рядах ...” [Ulyanov, 1956: 70]. Lenin also admired the heroism of the toreador's verses from "Carmen" [Essen 1969: 116], not perceiving them as an ironic characteristic that the author gave to the image of Escamillo.

Ureklian writes that Lenin liked Prince Eletskii's aria from "The Queen of Spades" by Tchaikovsky, “Я Вас люблю, люблю безмерно ...”. He sang it in Shushenskoe "always with great passion. And who knows, maybe Vladimir Lenin associated this musical expression of a passionate recognition with his memory of St. Petersburg, meeting Nadezhda Konstantinovna, and perhaps their joint visit of "The Queen of Spades" at the Mariinsky Theatre" [Ureklian, 1963: 68].

The Ulyanov family paid much attention to vocal lyrics: art songs, songs. M.M. Essen writes that "Lenin listened Tchaikovsky's "Night", "Amid the noise of the ball", "We sat together by a sleeping river" with great pleasure" [Essen 1969: 116]. One of the favourite works of Lenin in his youth was a duet "Sailors": music by K.P. Vilboa, poetry by N.M. Yazykov, a native of Simbirsk. The author's name of the verses was - "The Swimmer" and it was written in 1829 in Simbirsk. D.I. Ulyanov noted the strong impression the final verse made on Lenin, "Но туда выносят волны / Только смелого душой! ... / Смело, братья, бурей полный / Прям и крепок парус мой” [Ulyanov, 1956: 69]. Ureklian cites enthusiastic reviews about this work given by N.V. Gogol and I.V. Kireevsky, a famous Russian philosopher [Ureklian, 1963: 42].

According to D.I. Ulyanov, Lenin liked to sing "The Wedding" of Dargomyzhsky, "Нас венчали не в церкви / Не в венцах, не с свечами; / Нам не пели ни гимнов, / Ни обрядов венчальных!"[Ulyanov, 1956: 69]. Versees for this piece were written by A.V. Timofeev, 
also a native of Simbirsk, a poet, writer and playwright.

Krupskaya recalls on the Parisian emigration in 1909, "Ilyich willingly went to various cafes and suburban theaters to listen to revolutionary chanson singers who sang about everything in the working-class neighbourhoods - about drunken peasants choosing a travelling agitator to the Chamber of Deputies, about children education, unemployment and so on. Ilyich especially liked Montegyus. The son of a communard, Montegyus was loved by the working-class. However, in his improvised songs - always with a bright everyday colouring - there was no definition of any ideology, but there was a lot of sincere enthusiasm. Ilyich often hummed his greeting to the $17^{\text {th }}$ regiment, which refused to fire on strikers ..." [Krupskaya, 1960: 156]. It is clear that Lenin was touched by the immediacy of this singer's art. And in his letter to L.B. Kamenev in 1912, he cites the words of the greeting to the $17^{\text {th }}$ Regiment: "Salut, salut à vous ... Oh, I would love to listen to Montequs" [Lenin, 1982, T. 48: 75].

It is known that in London, Lenin, as he writes to M.A. Ulyanova, heard Tchaikovsky's Pathetique Symphony, which made a good impression on him [Lenin, 1983, T. 55: 229]. Z. Andreeva, referring to N.K. Krupskaya, said that Lenin "... was happily listening to the music by Rimsky-Korsakov, Borodin” [Andreeva 1968: 35].

In his book "Pages of Life of Issay Dobrowen "M.A. Dobroveyn writes, "I remember very well that Lenin and Gorky once listened to the Fourth Concert of Beethoven performed by Dobrowen at the Bolshoi Theater"4. And then specifies: musicologist S. Dreyden "reasonably believes that on October $4^{\text {th }}$, 1919, when Dobrowen performed the Fourth Concert of Beethoven with the orchestra conducted by S.A. Koussevitzky, Lenin was present in the Great Hall of the Conservatory" [Dobrowen, 1972: 59]. Unfortunately, Lenin's response to the performance of this work is unknown.

M.S. Kedrov, who played the piano for Lenin, recalls, "Ilyich liked the music by Beethoven the best", he names the Sonata Pathetique, Sonata in D Minor (obviously, the Sonata Op 31, number 17 E.P.), speaks about piano adaptations of overtures to the tragedies of Collin - "Coriolanus" and Goethe - "Egmont" that he performed [Kedrov, 1986: 459].

M. Dobrowen writes that when Lenin was a guest of Gorky, Issay Dobrowen was asked to play. He improvised on the Russian folk themes, then played Grieg, Chopin, Scriabin, his transcription of "Host of Kerzhenets" of the "Kitezh" by Rimsky-Korsakov and at the end Beethoven's "Appassionata". After that Lenin said the words, well-known from the records of Gorky [Dobrowen, 1972: 59]. "I know nothing better than "Appassionata", I would love to listen to it every day. It is amazing, superhuman music. I am always proud, perhaps naive, thinking that people can do such miracles!" [Gorky 1974: 42]. This Lenin's review gained the importance of winged words. However, this statement is deeply subjective. There are many other great works of the world musical culture.

Songs were an absolutely special field of music for Lenin. M.M. Essen recalls, "Vladimir Ilyich had a fairly pleasant, somewhat muffled voice and loved to sing in the choir and listen to the singing" [Essen 1969: 115]. They were mostly folk songs, or commonly referred to as folk. Ureklian approximately divides them by origin and story: about great rebels - Stepan Razin ("The Cliff"), Pugachev; Cossack songs of the Catherine the Great times; songs of Siberia ("The Storm Was Roaring", "Glorious Sea, Sacred Baikal" for the words of D.P. Davydov). Ureklian notes that, in addition to Russian songs, Lenin was interested in Ukrainian and Tatar songs, songs of the Jewish poor and the Polish revolutionary 
("Chervon Shtandar"), the revolutionary songs of France, Germany, Switzerland, Italy, Bulgaria. He notes that P.N. Lepeshinsky introduced Lenin to old folk revolutionary songs. And, of course, Lenin knew a lot of "forbidden" songs of convicts ("Tormented by Severe Servitude", "You Fell as Victims", "Dubinushka", "Rage, tyrants ...", "Warszawianka"), student songs [Ureklian, 1963: 3, 4, 62, 72]. As the glittering peak of this collection he saw the "Internationale".

When singing, Lenin outlined the revolutionary spirit of the songs. Essen recalls, that in the song "The Cliff", Lenin especially distinctly sang the verse, "Кто неправдой не жил, бедняка не давил. / Кто свободу как мать дорогую любил ... / И утёс-великан все, что думал Степан, / Все тому смельчаку перескажет" [Essen, 1969: 115].

Choral singing, one of the simplest and most common types of domestic music-making, was for Lenin both refreshing relaxation and an essential element of the festivities with family and friends, and an effective way of political declarations, especially on the May Day, in exile, at the party forums.

Nevertheless, there was music that caused rejection. Thus, Lenin, as M.S. Kedrov recalls, "could not stand" "Songs without Words" by Mendelssohn, considering them mawkish [Kedrov, 1986: 459]. Perhaps this was due to the fact that the sincerity and originality of the musical thinking of Mendelssohn appeared to be eclipsed by the flow of imitation, later called Mendelssohn's mediocrity, which created the corresponding intonation environment. Lenin also did not like Beethoven's Quartet (failed to figure out opus - E.P.), he listen to with N.K. Krupskaya in Krakow and which " put them into a terrible boredom, although one of our friends, a great musician (I.F. Armand - E.P.) was delighted" [Krupskaya, Lenin. 1983: 346-347]. The literature on the musical tastes of Lenin says nothing about his attitude to the composers, who had embodied the idea of impressionism, expressionism, to other brightest musical events and names of the 19th-20th centuries. Had not he heard of them? Had not he listened to them? Had not he liked them? Had not he shown any interest?

Nevertheless, Lenin had favourite performers: a dramatic tenor Yu.F. Zakrzewski, popular in the second half of the $19^{\text {th }}$ century, a pianist I.A. Dobrowen whom Lenin listen to not only in public concerts, but also at home. M. Dobrowen, referring to S. Vinogradskaya, cites the enthusiastic words of Lenin after the performance of the Sonata Pathetique of Beethoven performed by I. Dobrowen on April 23, 1920 in the concert department of the Communist evening on the occasion of the fiftieth anniversary of Lenin, "Dobrowen is the best. Excellent - wen, charming - wen! Wonderful - wonderful - wen ... “[Dobrowen, 1972: 58-59].

Friends and comrades recalled that Lenin was a rare listener - attentive, sensitive, sympathetic and deeply perceiving what he was listening to. M.M. Essen writes, "Sometimes after musical evenings (when vocal lyrics of Dargomyzhsky, Tchaikovsky and others was performed. - E.P.) we went to see off our quests (I was living in the house of Lenin at that time) and then returned home quitened, tired and somewhat sad. These songs did thrill something in our souls!" [Essen, 1969: 117].

And Lenin himself poetically told to I.F. Popov, "when we were children, I and my brother Sasha rode far away on our boat... and over the river sometimes a song is heard from out of nowhere... So great they are, the songs in Russia!" [Popov, 1960: 116].

Several times Lenin listened to the amateur pianist M.S. Kedrov. The musician recalls, "That evening I had to play a lot. Ilyich liked the music of Beethoven most of all. His sonatas - Pathetique and d-moll, his overtures 
"Coriolanus" and "Egmont". Lenin eagerly listened to some works by Schubert - Liszt ("King of the Forest", "Shelter"), preludes by Chopin ... You play exceptionally! - Lenin said about my performance ...". Then M.S. Kedrov says, "I think it is not my performance that is nothing special, but Vladimir Ilyich himself, his mood where the clue is" [Kedrov, 1986: 459].

P.N. Lepeshinsky writes that for Lenin there was no better way to relax from the cabinet work as to listen (I mentally transfer to the period of our emigratioin in 1904-1905) to the singing of Gusev (Drabkin) or violin performance by P.A. Krasikov with Lydia Aleksandrovna Fotieva playing the piano. Mr. Gusev had a very good, quite powerful and rich baritone, and when he beautifully sang, “нас-не-в церк-ви вен-ча-ли”, our whole Bolshevist family audience listened to him with bated breath, and Vladimir Ilyich, sitting back to the couch with his hands covering the knee, withdrew deeply into himself and apparently suffered some deep moods only he knew about. Or, for example, when P.A. Krasikov played clear lovely sounds of Tchaikovsky's Barcarolle with his violin, Vladimir Ilyich first, at the end of the performance, applauded and demanded repetition by all means" [Lepeshinsky, 1986: 451-452].

There is a drawing by P.V. Vasilyev which captured Lenin listening to the pianist G.I. Romanovsky playing at the home concert at A.D. Tsiurupa. In the apartment of Lenin in the Kremlin, there was a piano manufactured by Bechstein No. 49152 [Goldenstein, 1987: Insert with figures, P. 16].

L. Kuznetskaia in her book "The Music Library of the Ulyanov Family" provides a list of music scores and books, which were kept in the Kremlin apartment of Lenin. The music library with over four hundred scores and books, is basically a collection of popular music for the piano played individually or in a duet, as well as songs for the voice and the piano. Some of music scores had the signature of M.A. Ulyanova, on the literature that had been acquired before Lenin's moving to Moscow. A number of music publications were released during the life of Lenin - works by Bach, Haydn, Mozart, Schubert, Weber, Mendelssohn, Brahms, Schumann, Chopin, Bizet, Gounod, Massenet, Liszt, Donizetti, Verdi, Wagner, Halevy, Grieg, Strauss, Alyabiev, Gurilev, Varlamov, Verstovsky, Glinka, Dargomyzhsky, Bulakhov, A. Rubinstein, Tchaikovsky. In the library, there are piano scores of "La Sonnambula" by Bellini, "La Traviata" by Verdi and "Tannhauser" by Wagner, potpourri and fantasy on the themes of operas. The Fourth Hungarian Rhapsody by Liszt and "Danse Macabre" by Saint-Saens adapted for the piano. There are exercises by Ganon, Cramer and Czerny etudes [Kuznetskaia, 1985: 85-119]. All this, as we can see, is the literature of an enthusiastic amateur pianist.

There are not many books in the library, only thirty-eight. But there are the treatise "On Music" by Plutarch, works by E.M. Braudo: the first volume of the "General History of Music", the works about Borodin and Rimsky-Korsakov. There are papers published under the editorship of Nikolai Rimsky-Korsakov in 1922, pamphlets of I. Glebov about Mussorgsky, Chopin and a prospectus of the Persimfans (Author Unknown), published in 1922 [Kuznetskaia, 1985: 120 123]. This list also shows the desire for collecting literature in historical sequence, but the list is short.

Considering Vladimir Lenin's musical interests and priorities, the following conclusions can be made:

1. Contrary to the popular musicologists' desire to consider listening to music as a means of artistic enlightenment, what we cannot 
but agree with, Lenin considered, at least for himself, listening to music to be the best form of recreation.

2. Lenin's musical interests include works of the second half of the $18^{\text {th }}-19^{\text {th }}$ centuries, with the clearly expressed folklore basis, recognizable tones. The vast majority of these works are programme, which contributes to better orientation in the audio material. They include the genres most common for the life of the intelligentsia of the time - opera, diverse vocal lyrics. Symphonic music included Tchaikovsky's Sixth Symphony, Beethoven's overtures, some works of Borodin and Rimsky-Korsakov. As for the piano music, Lenin was most enthusiastic about Sonata Pathetique, Appassionata, Sonata No. 17 by Beethoven, Chopin's piano miniatures, some transcriptions of Liszt. He also admired the sound of the solo violin.

The folk songs, especially the revolutionary ones, were vivid musical landmarks for him. He often sang them with his supporters.

Colourful delicacy of impressionism, intensity of expressionism, a number of other distinctive phenomena of musical culture of the $19^{\text {th }}-20^{\text {th }}$ centuries, did not find any response in his heart.

Thus, the range of musical interests of Lenin was typical for most intelligent people of his time, who were not professional in this field.

3. He openly expressed his likes and dislikes in music. However, he had never given official critical estimates for works of art, rightly believing that such statements should be based on sound professional knowledge.

But being a wise philosopher, he obviously understood an infinite variety of language and forms in art. Is it because of this that he noted in the summary of the book by L. Feuerbach "Lectures on the Essence of Religion", "Art does not require the recognition of its works as real" [Lenin, 1963: 53].
4. Being a sensitive and spiritually rich person, who quickly felt the subject matter and essence of phenomena, Lenin clearly understood the powerful, almost hypnotic power of music and saw its positive and negative impacts, including himself. Therefore, after the enthusiastic words about Appassionata he said:

- But I cannot listen to music often, it gets on my nerves, I want to say sweet nothings and pat on the back of people who, living in a filthy hell, can create such beauty. And it is wrong to pat anybody on the back today, they will bite your hand tomorrow, and it is necessary to hit on the head, beat mercilessly, though we ideally are against any violence against people [Gorky 1974: 42].

At the same time, he saw the invigorant, inspiring and unifying power of music defined by its emotional impact on people. And he considered the music demonstrating the romance of high energy and pressure to be the priority for himself and the deed that he served. "I do not remember neither minor tones nor sadness in Lenin's singing, he always sounded courageous, daring, with high rise and appeal", D. Ulyanov wrote [Ulyanov, 1956: 70].

5. Being a philosopher, Lenin defines the role of art for mankind. The first phrase of this definition is widely known from the memories of Clara Zetkin: "Art belongs to the people". But then, Lenin develops his idea, "it should have its deepest roots in the very stratum of the working masses. It should be understood by these masses and loved by them. It should unite the feelings, thoughts and the will of the masses and raise them. It should awaken artists in them and develop them" [Zetkin, 1986: 462].

6. As a practical person, the creator of the first state with a new economic structure in the world, he determines the method of implementation of the above statement: "For art to come closer to the people, and the people to 
art, we must first raise the general educational and cultural level". And he explains, "illiteracy ... does not fit well with the task of restoring" [Zetkin, 1986: 462-463].

Then he declares with inspiration, “... our workers and peasants ... were entitled to have great art. Therefore, we have first focused on the most widespread popular education and upbringing. It paves the way for the culture ....". But he understood the complexity of the situation in the first years of the Soviet power: "... of course, provided that the problem of bread is solved" [Zetkin, 1986: 463].

L. Raaben writes, "In the $20 \mathrm{~s}$, orientation of representatives of musical art at the broader cultural and educational work with the masses has become a principle of the government position ...” [Raaben, 1969: 184]. This was preceded by the establishment of the system of state concert institutions.

On June 12, 1918, Lenin signed a decree "On the Transition of Petrograd and Moscow Conservatories to the People's Commissariat of Education”. On August 26, 1919 he signed a decree on the nationalization of theaters. The most significant of them received subsidy from the state.

Around this time, three state string quartets were established in Petrograd, which included prominent musicians: in 1917, the quartet named after Lunacharsky (I. Lukashevsky, I. Lidsky, V. Bakaleynikov, E. Wolff-Izrael), then the band was renamed into the quartet named after Glazunov; at the end of 1918 - the quartet named after Lenin (L. Zeitlin, K. Mostras, F. Krish, G.Pyatigorsky); in 1919 - the quartet named after Stradivari (supervised by D. Krein).

Being in the position of the continuity of the art development, Lenin in the severe winter of 1919 defends the importance of the theaters, which had "bourgeois" operas in their repertoire such as “Carmen", "La Traviata", "Eugene Onegin" and others [Lepeshinsky, 1986: 451]. In Vkhutemas, he opposed the subverters of "Eugene Onegin" with a humorous undertone [Sen'kin, 1986: 509510]. He assisted M.E. Pyatnitsky in collecting folk songs and organizing live performances [Petrishchevsky, 1986: 497].

Lenin expressed his point of view on the role of art culture in the country in the draft resolution of the Convention of the Proletkult, written on October 8, 1920 “... Marxism is far from rejecting the most valuable achievements of the bourgeois epoch, on the contrary, it has adopted and processed everything that was valuable during the period of more than two thousand years of the development of human thought and culture (today we can say five thousand years E.P.). Only further work on this basis and in this direction, inspired by the practical experience of the dictatorship of the proletariat as the last struggle against every form of exploitation, may be considered the development of a genuine proletarian culture" [Lenin 1981: 337].

Raaben writes that in the early years of the Soviet power the important role was played by free concerts for the public. "Only in the Winter Palace renamed into the Palace of Arts", says the scholar, "from the autumn of 1918 till the spring of 1919 (one season - E.P.) the State Symphony Orchestra and the Quartet named after Lunacharsky gave 96 free concerts for the people performing symphonies and ensembles by Mozart, Beethoven, Tchaikovsky, RimskyKorsakov, Borodin and other classical composers of Russian and foreign music" [Raaben, 1969: 179].

Thus, Lenin as a political leader thought of the art in its entire scope of its kinds, genres and forms - in the historical development - as the greatest treasure of the world culture, a powerful means of cultural education.

The embodiment of Lenin's idea of raising the cultural level of the working people began 
to spread from the $60 \mathrm{~s}$ of the $20^{\text {th }}$ century in the complex aesthetic education of youth. The issues of mass musical and aesthetic education were comprehensively and in detail discussed for the first time at the IV All-Union Convention of Soviet Composers in 1969. Realization of musical and aesthetic education had not been as successful as expected, but the work was carried extensively, and there were some positive results.

However, with the downfall of the myth of Lenin's understanding, omnipotence and absolute correctness in everything (including his musical interests and priorities) that was fervently created by the communist ideology, which he, as we can see, did not share, the idea of musical-aesthetic education of youth encountered the riff of the market economy as the measure of things created by public figures in the late $20^{\text {th }}$ century. Time has shown that the idea of comprehensive education (including aesthetic) of the man, the builder of the future (engineer, agrarian, humanitarian), has not lost its relevance.

Despite the fact that the Mass Media today is somehow not customary to speaking about the necessity of large-scale aesthetic education, and radio and especially television broadcast a flow of bad taste and dullness, the number of theaters, including music, orchestras (symphonic, chamber, wind, folk instruments), choirs and art actions in the country funded from the federal and local budgets and sponsors has increased significantly. It is an unconditional and clear sign of the need for art culture and its development. Further way of possible meeting this need in a better way can run only in line with systematic and consistent general music education.

Herewith, it is necessary to outline the difference between music education and enlightenment. These concepts are similar, but not identical.

Musical enlightenment is a set of concerts, plays, creative meetings and other forms of contact with the audience, when the repertoire and programmes are arranged in accordance with the plan and priorities of the art director, capabilities of the theater, philharmonic hall, concert bands, when the art of music is presented to a diverse audiences extensively and often at random. If the arrangement of events is good, concert organizations will have good profit and good press (three- or four-digit numbers of performances or concerts per year, month, week). The audience will be very happy applauding and, what is very important, turning to high art.

A higher level of organization of the audience is general music education. It is not teaching how to play a musical instrument. It means teaching people to listen. It is searching for the answer to the question, which is thrilling many people: how to listen and understand music? And it can be solved only by educational programmes in the field of music. Therefore, courses of listening to music (albeit small) with successive (from simple to complex) systematic presentation of the material - eras, styles, genres and forms - should be introduced into the curricula of secondary schools and universities. The experience of organizing such courses is available. But they should be introduced in all schools, all universities.

Such programmes will resultin the knowledge of musical culture and vision of the place occupied by the national music - a huge unique array based on the harmonious fusion of Russian, Ukrainian, Polish, Caucasian, Central Asian, Moldovan and other folklore basics. National music culture requires preservation and is worthy it. Like other types of national art, it is our historic memory of the glorious past, the majestic present and the bright future. Understanding the historical and global importance of national art is one of the ways of solid opposition to globalization, preservation of national cultural and art values, Russian mentality. 
A lot of works have been devoted to the thoughts on globalization. One of the latter, which considers its origin, processes and results, is the work of A. Sviatoslavskii "Globalization as a Factor of National Cultures' Alteration" [Sviatoslavskii, 2014: 76-80].

2 Roshal L.M., Doctor of Medical Sciences, Professor, Director of Research Institute of Urgent Children Surgery and Traumatology.

3 Another name of this opera by Halevy in Russian is "Dotch Kardinala" [Cardinal's Daughter].

4 Issay Aleksandrovich Dobrowen (1891-1953), a conductor, pianist, composer. Worked in Moscow, Dresden, Berlin, Sofia, San-Francisco, Milan. In 1941-45 conducted in the Royal Opera in Stockholm. He conducted on tours in many countries of Europe, the USA [Dobrowen, 1972].

\section{References}

1. Alshvang A., Zuckerman B. Liubimye proizvedeniia V. I. Lenina ("Appassionata” Betkhovena i Shestaia simfoniia Chaikovskogo) [Favourite Music of Lenin (Appassionata by Beethoven and Tchaikovsky's Sixth Symphony)]// Lenin i muzykal'naia kul'tura [Lenin and Musical Culture]. Moscow, 1970. Pp. 28-44.

2. Andreeva Z. Lenin liubil muzyku [Lenin Loved Music] // Rasskazy o muzyke [Stories about Music]. Moscow, 1968. Pp. 32-35.

3. Andronnikov I. K muzyke [Approaching Music]. Moscow: Sovetsky kompozitor, 1975. 336 p.

4. Dobrowen M. Stranitsy zhizni Isaiia Dobroveina [The Pages of Life of Issay Dobrowen]. Moscow: Sovetsky kompozitor, 1972. 208 p.

5. Dreiden, S.D. Lenin slushaet Betkhovena [Lenin Listening to Beethoven]. Moscow: Sovetsky kompozitor, 1975. $207 \mathrm{p}$.

6. Essen M. Vstrechi s Leninym [Meeting Lenin] // Vospominaniia o Vladimire Il'iche Lenine [Memories of Vladimir Ilyich Lenin]. In 5 volumes. V. 2. Moscow, 1969. Pp. 115-117.

7. Goldenstein M.L. V.I. Lenin i muzyka [V.I. Lenin and Music]. Leningrad: Muzyka, 1987. 96 p.

8. Gorky M. V.I. Lenin [V.I. Lenin] // Gorky M. Collection of Works. in 30 volumes. V. 20. Moscow: Nauka, 1974. Pp. 7-49.

9. Kassil L. Doveriaias' muzyke [Trusting in Music] // Rasskazy o muzyke [Stories about Music]. Moscow, 1968. Pp. 12-14.

10. Kedrov M. Iz krasnoi tetradi ob Il'iche [From the Red Notebook about Ilyich] // V.I. Lenin o literature $i$ iskusstve [V.I. Lenin about Literature and Art]. 7th Edition, revised. Moscow, 1986. P. 459.

11. Konionkov S. Umei slushat' [Learn To Listen] // Rasskazy o muzyke [Stories about Music]. Moscow, 1968. p. 11.

12. Krupskaya N.K. and Lenin V.I. Pis'mo k M.A. Ul'ianovoi 26 dekabria 2913 g. [Letter to M.A. Ulyanova dated December 26, 1913] // Lenin V.I. Complete Collection of Works. $5^{\text {th }}$ Edition. Moscow: Politizdat, 1983. V. 55. Pp. 346-347.

13. Krupskaya N.K. Chto ponravilos' Il'ichu iz khudozhestvennoi literatury [What Literature Did Ilyich Like] // O Lenine. Vospominaniia, rasskazy, ocherki [About Lenin. Memoirs, Stories and Essays]. Moscow, 1960. Pp. 155-160.

14. Kuznetsakaia L. Notnaia biblioteka sem'i Ul'ianovykh [Music library of the Ulyanov Family]. $3^{\text {rd }}$ Edition, revised and enlarged. Moscow: Sovetsky kompozitor, $1985.128 \mathrm{p}$.

15. Lenin V.I. O proletarskoi kul'ture. Proekt resolutsii [About the Proletarian Culture. Resolution Draft] // Lenin V.I. Complete Collection of Works. $5^{\text {th }}$ Edition. Moscow: Politizdat, 1981. V. 41. P. 337. 
16. Lenin V.I. Konspekt knigi Feierbakha "Lektsii o sushchnosti religii" [Summary of L. Feuerbach's Book "Lectures on the Essence of Religion"] // Lenin V.I. Complete Collection of Works. $5^{\text {th }}$ Edition. Moscow: Politizdat, 1963. V. 29. Pp. 41-64.

17. Lenin V.I. Pis'mo L.B. Kamenevu 30 iiulia 1912 g. [Letter to L.B. Kamenev dated July 30,192] //Lenin V.I. Complete Collection of Works. $5^{\text {th }}$ Edition. Moscow: Politizdat, 1982. V. 48. P. 75.

18. Lenin V.I. Pis'mo M.A. Ul'ianovoi 9 fevralia 1901 g. [Letter to M.A. Ulyanova dated February 9, 1901] // Lenin V.I. Complete Collection of Works. $5^{\text {th }}$ Edition. Moscow: Politizdat, 1983. V. 55. P. 202.

19. Lenin V.I. Pis'mo M.A. Ul'ianovoi 4 fevralia 1903 g. [Letter to M.A. Ulyanova dated February 4, 1903] // Lenin V.I. Complete Collection of Works. $5^{\text {th }}$ Edition. Moscow: Politizdat, 1983. V. 55. P. 229.

20. Lepeshinsky P.N. Iz knigi "Na povorote" [From the Book "At the Turn"] // V.I. Lenin o literature i iskusstve [Lenin about Literature and Art]. Moscow, 1986. Pp. 451-452.

21. Petrishchevsky D. Iz besedy s sobiratelem russkoi pesni M.E. Pyatnitsky [From the Interview with the Collector of Russian Songs M.E. Pyatnitsky] // V.I. Lenin o literature i iskusstve [Lenin about Literature and Art]. $5^{\text {th }}$ Edition. Moscow, 1986. P. 497.

22. Popov I. Lenin v Briussele [Lenin in Brussels] // Vospominaniia o Lenine [Memoirs About Lenin]. Moscow, 1960. V. 3, p. 116.

23. Raaben L.N. Leninskie idei prosveshcheniia mass i ikh pretvorenie v sovetskoi muzykal'noi zhizni [Lenin's Ideas of Enlightening the Masses and Their Implementation in the Soviet Music Life] // Uchenie V.I. Lenina i voprosy muzykoznaniia [Lenin's Thought and the Issues of Music Study]. Leningrad, 1969. Pp. 172-202.

24. Rozenschild K. Lenin i muzyka [Lenin and Music] // Lenin i muzykal'naia kul'tura [Lenin and Music Culture]. Moscow, 1970. Pp. 5-27.

25. Sviatoslavskii A.V. Globalizatsiia kak factor izmeneniia natsional'nykh kul'tur [Globalization as a Factor of Alteration of National Cultures] / Voprosy kul'turologii [Issues of Culture Study] . 2014. No. 6. Pp. 76-89.

26. Sen'kin S. Lenin v commune Vkhutemasa [Lenin in the Community of the Vkhutemas] // V.I. Lenin o literature i iskusstve [V.I. Lenin about Literature and Art]. 7-е изд. М., 1986. C. 506-510.

27. Steinpress B. Zakrzewski // Muzykal'naia entsiklopediia [Muscial Encyclopedia]. Moscow, 1974. V. 2. P. 430.

28. Ulyanov D.I. Liubov' $k$ muzyke [Love for Music] // Vospominaniia o V.I. Lenine [Memoirs of V.I. Lenin]. V. 1. Moscow, 1956. Pp. 69-70.

29. Ureklian L.A. Lenin i muzyka [Lenin and Music]. Moscow, 1963. 78 p. Manuscript.

30. Volkonskii M. "Vo glubine sibirskikh rud...” ["In the Depth of Siberian Ores...”] // Rasskazy o muzyke [Stories about Music]. Moscow, 1968. pp. 145-148.

31. Vospominaniia Poliny Annenkovoi [Memoirs of Polina Annenkova]. Kranoyarsk: Kranoiarskoe knizhnoe izdatel'stvo, 1977. $328 \mathrm{p}$.

32. Zetkin C. Iz knigi "O Lenine" [From the Book "About Lenin"] // V.I. Lenin o literature $i$ iskusstve [V.I. Lenin about Literature and Art]. Moscow, 1986. Pp. 461-464. 


\section{Музыкальные интересы \\ и приоритеты В.И. Ленина \\ (современное видение)}

\section{Э.М. Прейсман}

Красноярская государственная академия музыки и театра Россия, 660049, Красноярск, ул. Ленина, 22

В современной России обрела актуальность проблема духовного воспитания, в том числе музыкально-эстетического, как одного из барьеров на пути распространения негативных влияний глобализации. В постперестроечные годы работа по духовному воспитанию значительно сократилась. В поисках современных подходов кее восстановлению необходимо обратиться к опыту прошлого и, в частности, осмыслить отношение к музыке В.И. Ленина, который, будучи в этой области дилетантом, как государственный деятель видел в художественном воспитании населения целесообразность и перспективу.

Ключевые слова: Ленин, музыка, музыкально-эстетическое образование, опера, симфоническая музыка, квартет, фортепианная музыка, вокальная лирика, романсы, песни.

Научная специиальность: 17.00.00-искусствоведение. 